\title{
The Criteria of Residential Satisfaction in Gated Community: Medan City
}

\author{
Dwira Nirfalini Aulia a , Abdul Majid Ismail ${ }^{b}$ \\ a Faculty of Engineering University of Sumatera Utara, Indonesia \\ ${ }^{b}$ School of Housing Building and Planning, University Science Malaysia \\ dwira.nirfalini@usu.ac.id
}

\begin{abstract}
Investigation on residential satisfaction can be conducted to answer the question on how to plan a housing area which can be accepted by the middle income society. The main objective of this research is to identify the criteria of residential satisfaction and determine the expected housing criteria required in the overall planning of a housing area. The research conducted using cross-sectional survey method, field investigation and picture. It is discovered that housing location, housing design and public facilities are physical satisfaction criteria and security, social interaction and housing tenure are non physical criteria.
\end{abstract}

Keywords: Residential satisfaction; gated community; housing criterion; policy implication

eISSN: 2398-4295 @ 2016. The Authors. Published for AMER ABRA by e-International Publishing House, Ltd., UK.. This is an open access article under the CC BY-NC-ND license (http://creativecommons.org/licenses/by-ncnd/4.0/). Peer-review under responsibility of AMER (Association of Malaysian Environment-Behaviour Researchers), ABRA (Association of Behavioural Researchers on Asians) and CE-Bs (Centre for EnvironmentBehaviour Studies), Faculty of Architecture, Planning \& Surveying, Universiti Teknologi MARA, Malaysia.

https://doi.org/10.21834/ajbes.v1i3.37 


\subsection{Introduction}

Housing demand continues to increase along with the increase of population. However, purchasing ability does not always increase accordingly. This situation leads to the gap in housing supply and demand in Medan city. Housing demand characteristics should be thoroughly examined to establish market interest in the type of house, especially for middleincome population. One indicator to determine housing demand characteristics is residential satisfaction. Aspects that affect occupant satisfaction are variables for the family or the residents of the city to select the location and the neighborhood to live in (Asha, 1984). By knowing the aspects that affect satisfaction and dissatisfaction of the residents, we will know the tendencies for families to choose a neighborhood.

Occupant's responses to their neighborhood can be shown from their adaptation (Plaut and Plaut, 2010). Occupants can physically adapt by changing their residence or neighborhood (Tipple \& Salim, 1999; Sinai, 2001) or by moving away to another location (Han \& Baum, 2002). Every occupant moving away to another location has different criteria to select housing type and location. In this selection process, residential satisfaction becomes the main reason. Regional sections for inhabitation can be called as residential preferences (Varady 2001). Residential satisfaction is more focused on the occupant's attitude towards their residence and neighborhood (Francescato, 1987; Bajunid et al., 2012). Based on the discussion above, despite knowing the criteria of the residential satisfaction, we will surely know the aspect that affect the human being.

The purpose of this study is to identify the residential satisfaction criteria of gated community in Medan city. The discoveries about residential satisfaction can be contribute to housing scheme planning in the city.

\subsection{Literature Review}

The concept of residential satisfaction in this study based on three theories namely the theory of the relationship between man and his environment (Amerigo \& Aragones, 1997), residential satisfaction theory (Michelson, 1977) and the theory of the purposes of human life. (Maslow, 1958; Marans \& Rodgers, 1975). The relationship between the theory of man and his environment can be described as follows: (1) individual interaction with housing environment viewed from the cognitive aspects (2). Interaction of individuals with the housing environment viewed from the aspect of the state can be shown from the form of residential satisfaction (3). Interaction of individuals with the housing environment from the aspects of behavior, by looking at the behavior of the individual against the housing environment such as social interaction with neighboring residential, housing estate management, cooperation in environmental activities and others. Michelson (1977) states that the residential satisfaction can be viewed from three aspects namely mobility and choice, needs and behavior of residents with their environment. Residential satisfaction can be seen when they ready to settle option to adapt to the environment or make the decision 
move the residence to different locations. (Marans \& Rodgers, 1975) states that housing expectation, the level of need and the value of the home will increase accordingly with the increase in economic ability.

\subsection{Gated community}

Gated community is a group of people who live in the area that has a similarity in certain aspects such as ethnicity, income, social class (Grant \& Jill, 2005). This community bordering the residential area to keep themselves from the risk of crime and things that are undesirable (Rowlan \& Flint, 2005). This area was given a fence and gate to have control or restrictions on access to residential areas. Residential gated area is a closed residential area where public spaces legally in privatization. Limited access to residential gated area usually run by residents associations that compile and run the rule. (Roitman, 2005; Thuillier, 2005; Atkinson, 2005).

\subsection{Methodology}

Limitations in residential satisfaction research are one of the consideration in designing the research methodology. Post Occupancy Evaluation method used to conduct this research. Data can be collected by using cross-sectional survey method. Primary data is obtained by distributing the questionaire, field observations and image recording (Bechtel et al, 1987). Limitation the scope of the research carried out by: (1). The reason for choosing housing area (2). Occupant satisfaction grouping criteria into physical and non-physical aspects (3). Group size of the region under study ranging from the micro-scale (neighborhood) to the macro scale (urban). (4). Housing types under study is planned housing.

The research population is the middle-income community in Medan city, which can be devided into five sub regions. Research sample are taken from a housing estate in each subregion. Criteria for housing sample selection based on: (1). Residential location chosen as the sample based on structures of Medan City. (2). Occupation duration at least 5 years. (3). The size of the housing estate at least 300 housing units, based on the most modest housing scale. There were 1418 questionnaires distributed, and only 1294 respondents completed questionnaires and can be analyzed. Observation and image recordings conducted by reviewing the social and behavioral aspects of the residential occupants such as places of social interaction, lifestyle, residents behavior and others.

Respondents research are taken in clusters based on the duration of occupation, location of residence and ease of accessibility. Structured questionnaire developed by the group (1). Resident's background (2). Current housing conditions (3). Housing facilities (4). Resident's desire for future. Therefore, there are several limitations of the study residential satisfaction, the research done by looking at three impressions respondents namely: by comparing the previous residential satisfaction criteria, present and future desires. Data 
collected in this study are primary data and secondary data. Grouping variable and the data can be seen in Table 1 below.

Table 1: Research methodology

\begin{tabular}{|c|c|c|}
\hline Variables & Data Collecting Method & Data Analysis Method \\
\hline \multicolumn{3}{|l|}{ PHYSICAL ASPECT } \\
\hline $\begin{array}{l}\text { Location } \\
\text { Urban } \\
\text { Sub urban }\end{array}$ & $\begin{array}{l}\text { Primary data: } \\
\text { Questionnaire and } \\
\text { Observation. } \\
\text { Secondary Data: Medan } \\
\text { City Map }\end{array}$ & $\begin{array}{l}\text { Quantitative Method } \\
\text { Qualitative Method } \\
\text { (comparing satisfaction } \\
\text { based on housing } \\
\text { location) }\end{array}$ \\
\hline $\begin{array}{l}\text { Housing Facility } \\
\text { Electricity } \\
\text { Water } \\
\text { Drainage } \\
\text { Solid Waste system } \\
\text { Health Facilities } \\
\text { Education Facilities } \\
\text { Shopping Facilities } \\
\text { Open Space } \\
\text { Public Transportation }\end{array}$ & $\begin{array}{l}\text { Primary data: } \\
\text { Questionnaire and } \\
\text { Observation. }\end{array}$ & $\begin{array}{l}\text { Quantitative Method } \\
\text { Qualitative Method } \\
\text { (comparing level of } \\
\text { important with level of } \\
\text { satisfaction about } \\
\text { housing facility) }\end{array}$ \\
\hline $\begin{array}{l}\text { Housing Layout typology } \\
\text { Neighbourhood } \\
\text { House type }\end{array}$ & $\begin{array}{l}\text { Primary data: } \\
\text { Questionnaire and } \\
\text { Observation. } \\
\text { Secondary Data : Layout } \\
\text { housing }\end{array}$ & $\begin{array}{l}\text { Quantitative Method } \\
\text { Qualitative Method } \\
\text { (comparing satisfaction } \\
\text { based on pattern of } \\
\text { layout housing) }\end{array}$ \\
\hline \multicolumn{3}{|l|}{ NON PHYSICAL ASPECT } \\
\hline Social Interaction & $\begin{array}{l}\text { Primary Data: } \\
\text { Questionnaire }\end{array}$ & $\begin{array}{l}\text { Quantitative Method } \\
\text { Qualitative Method } \\
\text { (correlation between } \\
\text { resident profile and } \\
\text { social interaction) }\end{array}$ \\
\hline $\begin{array}{l}\text { Security } \\
\text { Housing Estate } \\
\text { Management }\end{array}$ & $\begin{array}{l}\text { Primary data: } \\
\text { Questionnaire and } \\
\text { Observation. }\end{array}$ & $\begin{array}{l}\text { Quantitative Method } \\
\text { Qualitative Method } \\
\text { (correlation between } \\
\text { resident profile and } \\
\text { security type) }\end{array}$ \\
\hline
\end{tabular}


Aulia, D.N. \& Ismail, A.M. / Asian Journal of Behavioural Studies, AjBeS, 1(3) Sep / Oct 2016 (p.43-52)

$\begin{array}{ll}\text { Ownership status } & \text { Primary Data : } \\ \text { Questionnaire } & \text { Quantitative Method } \\ & \text { (correlation between } \\ & \text { resident profile and } \\ & \text { ownership status ) }\end{array}$

\subsection{Results and Discussions}

Occupants profile for the study area is a collection of working age people, currently has a family and number of family members between $4-5$ people with male head of the family. Included in the middle-income population are families with income between $\mathrm{Rp} \mathrm{2,000,000} \mathrm{-}$ Rp 2,500,000 a month, high education, employed by private companies. Social dynamics that formed in the housing area communities in Medan is stable with most residents living in the housing area for $1-5$ years and most of them are homeowners.

Residential satisfaction criteria which included in the physical aspect are the housing location, housing facilities and housing layout. Housing preferences and choices operate within the framework of preferences and choices for housing attributes (Zinas \& Jusan, 2010). Residential location in the city structure is one of the criteria that are being considered by occupants in order to measure the level of satisfaction. (Michelson, 1977; Morrison, 1999; Aulia, 2001). Most residents use cars to go to work, so public transport is not a criterion for residential satisfaction. Shopping facilities are public facilities that became the main desires of residents. Through a common observation in twelve housing complex, ease of access to purchase general goods are available in the housing complex. When compared with the completeness of public facilities, housing estate management is a more important criterion. This finding is consistent with the research (Al Momani, 2003) which states that the management of the housing environment is an aspect that affects the quality of residential neighborhoods, particularly the management of public facilities and residential neighborhoods. Research on housing location preferences suggests that occupants prefer living in sub city area. Downtown area tends to be noisy, polluted and congested which limits open space. Occupants demand for new housing that comfort like home and have larger open spaces. The discovery is consistent with (Nelson \& Sanchez, 1997) in which groups the location of middle-income housing into two groups namely urban and sub-urban.

Residential satisfaction criteria which included in the non-physical aspects are social interaction, housing security and ownership status. Social interaction both within residential areas will increase the housing residential satisfaction. Morrison (2003) states that there are three aspects that affect the social dynamic of a neighborhood namely housing tenants and homeowners ratio, identity of ethnic culture as well as the balance between residents who move in and out of the housing complex. From another angle, social change continues to apply, and neighborhood relationships are also changing, because humans as social beings will see the functions in the social structure to meet the social needs in the community. 
(Tjahyono, 2004). The criteria of residential security are an essential issue for occupants to consider in choosing private residential areas. But the security is left entirely to the security guard at the gated residential area. Unlike the discovery of (Karim \& Rashid, 2010) that community participation in security have helped to foster positive community relation. This discovery may explain the phenomenon of the gated residential area that became popular in the last decade. Sakip et al (2013) have prove that within the context of gated and non gated community, respondents who occupy individual gated residential areas demonstrate a higher fear of crime when compared to their counterparts who live in non gated residential areas. This phenomenon does not only happen in Indonesia (Leisch, 2002) but also in the whole world. The reasearch discovered that home ownership related with marriage status, age of head of family, occupation, income and length of stay. This research discovery also demonstrated that a stable social dynamic in housing shows high social interaction in the housing area.

Criteria for middle-income security are security zone communities (Blakely \& Snyder, 1995), which formed in response to increasing insecurity. The gates function merely creates the feeling of secure. In addition, it is also function as symbolical mark to limit residential areas. Housing management institutes are needed in managing the housing area. Research findings indicate the ratio of homeowners to renters in the study area is $3: 1$. This detection rate is not much different to the report (World Bank, 2003) those comparisons of homeowners: lessee in Indonesia is $71 \%: 22.9 \%$. Ownership status becomes a pull factors for residents in choosing a home. Private developers offering home ownership status will attract more residents to buy a home than Right of Use Building. This study found that occupant satisfaction criteria can be illustrated in the schematic as seen in Fig. 1 below.

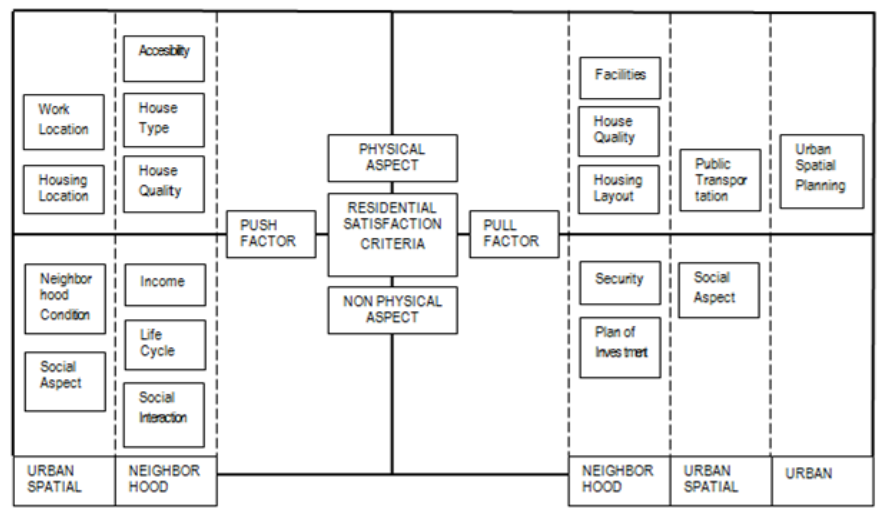

Figure 1: The criteria of residential satisfactions

Locations of the respondent's residence are mostly within 10-40 km from the city center. Research findings demonstrated that settled preference to sub-urban areas is the result of 
evaluating the condition of the occupants of the crowded city center. Settled preferences will affect Urban Spatial Structure Plan. Housing growth trends in the sub-region city should be anticipated in the drafting of the spatial structure of the city. Preferences settled into suburban areas causing the high demand for middle income housing in the region, therefore, increasing the land prices. The results showed that residential mobilisation tends to move to another similar housing layout typology. This discovery suggests residents are quite satisfied with the typology of gated residential community. Reasons why occupants mobilisation happened may relate to stages in an occupant's life cycle. This discovery strengthens the theory of Maslow's hierarchy which says that need in human life related to changes in its own social hierarchy. (Zavei \& Jusan, 2012).

Selection of occupancy is an essential decision-making process for mobile residents. Based on the analysis it can be concluded that desired criteria for residential satisfaction lies in the pull factors such as a strategic location, well-equipped public facilities, a safe environment and good accessibility. Residential gated community already provides these pull factors because occupants prefer complete residential areas that already meet their satisfaction. Based on the formula above, we need to have better supervision in order to grant permission for the development of residential areas, especially with regard to the accessibility of residential areas. Planning accessibilities in residential areas will affect the growth and changes in land use around the housing. Accessibility planning in residential areas have to be anticipated in view of public transportation that are not being a top choice for occupants which would give weight to the urban transportation network. (Nurlaela \& Curtis, 2012).

Management of private housing is starting to grow as the number of housing growth in the form of the gated community. At first, the management is organized by developers who developed residential area, but after all the houses are inhabited, the residential community is establishing a housing association housing manager (Mc Kenzie, 2005). This situation will cause problems to the city manager because this state would be contrary to the process of managing a residential area that is managed by the government. City government appoint the neighborhood chief in order to take care of the residential neighborhood. Therefore, further research needed to determine the benefits of applying the concept of designing residential housing to environmental management.

\subsection{Conclusion}

The study found that the perception of the occupants of the residence environment influenced by socio-economic background, duration of occupation, the type and location of residence. The discovery is consistent with a systematic model of residential satisfaction (Amerigo \& Aragones, 1977). The criteria consist of residential satisfaction physical factors (location of residence, type of residence and ordinary residential area convenience) and non physical factors (security, social interaction and residence ownership legislation). The 
discovery is also consistent with (Parkes et al, 2002) which also incorporate physical and non physical aspects in the investigation. Residential satisfaction criteria found in this study give direction to research housing plan based on housing demand.

Discussion and comparison study conducted by three scales namely geographical scale, urban spatial scale, and residential neighborhood. Implications of research findings to government regulations need to be investigated further, therefore that Housing Guidelines can be arranged to manage the physical and non-physical design of a residential area to create a comprehensive residential design. The permit of residential development should consider the residential satisfaction criteria that are not entirely left to the mechanism of the housing market.

\section{Acknowledgement}

This study was made possible by the support from Department of Architecture University of Sumatera Utara.

\section{References}

Al-Momani, A. A. (2003). Housing quality: Implications for design and management. Journal Urban Planning and Development, 177-184.

Amerigo, M. \& Aragonest, I. (1997). A theoretical and methodological approach to the study of residential satisfaction. Journal of Environmental Psychology, 17, 47-57.

Asha, S. (1984). Perception of living environment and residential planning. Journal of School of Planning and Architecture New Delhi, 6, 72-98.

Atkinson, R. \& Blandy, S. (2005). Introduction : International perspectives on the new enclavism and the rise of gated communities. Housing Studies, 20(2),177-186.

Aulia, D. N. (2001). Research of Housing Location, Site Plan and Residential Satisfaction. Presented in Proceeding SDPF Research, Jakarta.

Bajunid, A. F. I., Abbas, M. Y. \& Nawawi, A. H. (2012). Tessellation planning: Relationships between the physical environment and the neighbourhood. Asian Journal of environment-Behaviour Studies, 3(7), 45-56.

Bechtel, R. B., Marans, R. W., \& Michelson, W. (1987). Methods in environmental and behavioral research. New York: Van Nostrand Reinhold Company.

Blakely, E. J. \& Snyder (1995). Fortress America - Gated communities in the United State. 2nd edition. Washington: Brooking Institution Press.

Francescato, G. et al. (1987). Residential Satisfaction: Its uses and limitation in housing research. In Willem et al Eds, Housing and neighborhoods, theoretical and empirical contribution. New York: Greenwood Press. 
Grant, J. (2005). Planning Responses to gated communities in Canada. Housing Studies, 20(2), 273-285.

Han, J. H. \& Baum, S. (2002). Residential mobility in the Seoul Metropolitan Region where and why? The International Scope Review, 4(8), 546-560.

Karim, H. A. \& Rashid, S. M. A. (2010). Community participation : Towards a safer housing environment. Asian Journal of Environment Behavior, 19-33.

Leisch, H. (2002). Gated communities in Indonesia. Cities, 19(5), 341-350.

Marans, R. W. \& Rodgers, S. W. (1975). Toward an understanding of community satisfaction. In A Hawley and V.Rock, Eds, Metropolitan America in contemporary perspective. New York: Halstead Press.

Maslow, A. H. (1958). A dynamic theory of human motivation. Cleveland USA : Howard Allen Publishers.

Mc Kenzie, E. (2005). Constructing the Pomerium in Las vegas: A case study of emerging trends in American gated community. Housing Studies, 20(2), 187-203.

Michelson, W. (1977). Environmental choice, human behavior, and residential satisfactin. New York: Oxford University Press.

Morrison, N. (2003). Neighbourhoods and social cohesion: experiences from Europe. International Planning Studies, 8(2), 115-138.

Nelson, A. C. \& Sanchez, T. W. (1997). Exurban and suburban households: A departure from traditional location theory? Journal of Housing Research, 8(2), 249-276.

Nurlaela, S. \& Curtis, C. (2012). Modeling household residential location choice and travel behavior and its relationship with public transport accessibility. Procedia - Social and Behavioral Sciences, 54, 56-64.

Parkes, A., Kearns, A. \& Atkinson, R. (2002). What makes people dissatisfied with their neighbourhoods? Urban Studies, 39(13), 2413-2438.

Plaut, P. O. \& Plaut, S. E. (2010). Decision to renovate and to move. JRER, 34(2), 461-484.

Roitman, S. (2005). Who segregates whom? The analysis of a gated community in Mendoza, Argentina. Housing Studies, 20(2), 303-321.

Rowland, A. \& John, F. (2005). Fortress UK? Gated communities, the spatial revolt of the elites and time space trajectories of segregation. Retrieved from www.neighbourhoodcentre.org.uk

Sakip, S. R. M., Abdullah, A. \& Salleh, M. N. M. (2013). Fear of crime in residential areas. Asian Journal of Environment-Behavior Studies, 4(11), 27-39.

Sinai, I. (2001). Moving or improving: housing adjustment choice in Kumasi, Ghana. Housing Studies, 16(1), 97114.

Thuillier, G. (2005). Gated communities in the metropolitan area of Buenos Aires, Argentina: A challenge for town planning. Housing Studies, 20(2), 255-271.

Tipple, A. G. \& Salim, A. (1999). User-initiated extentions as housing supply, A study of Government - built low cost housing estates in Malaysia. TWRP, 21(2), 119-154. 
Tjahyono, Y. P. S. (2004). Perumahan bagi masyarakat berpenghasilan menengah kebawah di perkotaan (Sumbang saran bagi kemajuan Perum Perumnas pada ultah ke-29). Dimensi Teknik Arsitektur, 32(2), 171-178.

Varady, D. P. (2001). The impact of city/suburban location on moving plans: A Cincinnaty study. Growth and Change, 12, 35-49.

World Bank (2003). Kota - kota dalam transisi: Tinjauan sektor perkotaan pada era desentralisasi di Indonesia. Urban Sector Development Unit, Infrastructure Department, East Asia and Pasific Region, June 30 , 2003, Dissemination Paper No. 7.

Zavei, S. J. A. P. \& Jusan, M. M. (2012). Exploring housing attributes selection based on Maslow's hierarchy of needs. Procedia - Social and Behavioral Sciences, 42, 311-319.

Zinas, B. Z. \& Jusan, M. M. (2010). Choice behavior of housing attributes: Theory and measurement. Asian Journal of Environment Behavior Studies, 1-18. 